\title{
L-Malate Enhances the Gene Expression of Carried Proteins and Antioxidant Enzymes in Liver of Aged Rats
}

\author{
X. ZENG ${ }^{1,2^{*}}$, J. WU $^{1^{*}}$, Q. WU ${ }^{1}$, J. ZHANG ${ }^{1}$ \\ *These authors contributed equally to this work. \\ ${ }^{1}$ State Key Laboratory of Applied Microbiology Southern China, Guangdong Provincial Key \\ Laboratory of Microbial Culture Collection and Application, Guangdong Institute of Microbiology, \\ Guangzhou, China, ${ }^{2}$ College of Life Science and Technology, Jinan University, Guangzhou, China
}

Received January 18, 2014

Accepted July 1, 2014

On-line September 5, 2014

\section{Summary}

Previous studies in our laboratory reported L-malate as a free radical scavenger in aged rats. To investigate the antioxidant mechanism of L-malate in the mitochondria, we analyzed the change in gene expression of two malate-aspartate shuttle (MAS)-related carried proteins (AGC, aspartate/glutamate carrier and $\mathrm{OMC}$, oxoglutarate/malate carrier) in the inner mitochondrial membrane, and three antioxidant enzymes (CAT, SOD, and $\mathrm{GSH}-\mathrm{Px}$ ) in the mitochondria. The changes in gene expression of these proteins and enzymes were examined by real-time RT-PCR in the heart and liver of aged rats treated with L-malate. L-malate was orally administered in rats continuously for 30 days using a feeding atraumatic needle. We found that the gene expression of OMC and GSH-Px mRNA in the liver increased by $39 \%$ and $38 \%$, respectively, in the $0.630 \mathrm{~g} / \mathrm{kg} \mathrm{L-malate}$ treatment group than that in the control group. The expression levels of SOD mRNA in the liver increased by $39 \%, 56 \%$, and $78 \%$ in the $0.105,0.210$, and $0.630 \mathrm{~g} / \mathrm{kg} \mathrm{L-malate} \mathrm{treatment}$ groups, respectively. No difference were observed in the expression levels of AGC, OMC, CAT, SOD, and GSH-Px mRNAs in the heart of rats between the L-malate treatment and control groups. These results predicted that L-malate may increase the antioxidant capacity of mitochondria by enhancing the expression of mRNAs involved in the MAS and the antioxidant enzymes.

\section{Key words}

L-malate • Mitochondria antioxidant • Malate-aspartate shuttle • Real-time reverse transcription polymerase chain reaction (Realtime RT-PCR)

\section{Corresponding author}

J. Zhang, Guangdong Institute of Microbiology, Guangzhou 510070, China. Fax: 86-20-8768-0942. E-mail: Zhangjm926@126.com and J. Wu, Guangdong Institute of Microbiology, Guangzhou 510070, China. Fax: 86-20-3207-9835. E-mail: microwjl@yahoo.com

\section{Introduction}

L-malate, an important intermediate in the process of metabolism, has an important function in generating mitochondrial ATP under aerobic and hypoxic conditions. L-malic acid was recognized as a safe, nontoxic, harmless, and edible organic acid in 1967 by the U.S. Food and Drug Administration. As a tricarboxylic acid cycle intermediate, L-malate can be easily absorbed into the mitochondrion through the cell membrane, and promotes energy production in the mitochondria (Bobyleva-Guarriero and Lardy 1986).

The mitochondria provide an energy infrastructure for the cells and entire organism to maintain physiological activity. In our previous studies, we found that L-malic acid reduces oxidative stress (Wu et al. 2008) and increases the mitochondrial antioxidative defenses (Wu et al. 2011). L-malate significantly reduces reactive oxygen species (ROS) and malondialdehyde content levels in the liver and heart of aged rats. Supplementation of L-malate improves the activities of nicotinamide adenine dinucleotide (NADH)-dehydrogenase, NADH-cytochrome c oxidoreductase, and cytochrome c oxidase in the liver of 
aged rats. Moreover, studies have shown that L-malate can significantly increase the antioxidative defense system with an increased activity of antioxidant enzymes, such as superoxide dismutase (SOD) and glutathione peroxidase (GSH-Px), in the liver of aged rats. This enhancement in enzyme activity can be attributed to the improvement in the rate of the malate-aspartate shuttle (MAS) by L-malate (Wu et al. 2007), which can provide the substrate, NADH, for the electron transport chain. However, this mechanism remains unclear. As shown in Figure 1 (Scholz et al. 2000), L-malate has a central function in the transfer from cytosolic NADH to mitochondrial NADH (Eto et al. 1999). L-malate crosses the inner mitochondrial membrane in exchange for oxoglutarate via the oxoglutarate/malate carrier (OMC). Oxaloacetate, which is formed within the mitochondrial matrix as NADH is regenerated, cannot diffuse directly across the inner mitochondrial membrane and must react with glutamate to form aspartate. Aspartate is then exchanged with glutamate via the aspartate/glutamate carrier (AGC) to the inner mitochondrial membrane.

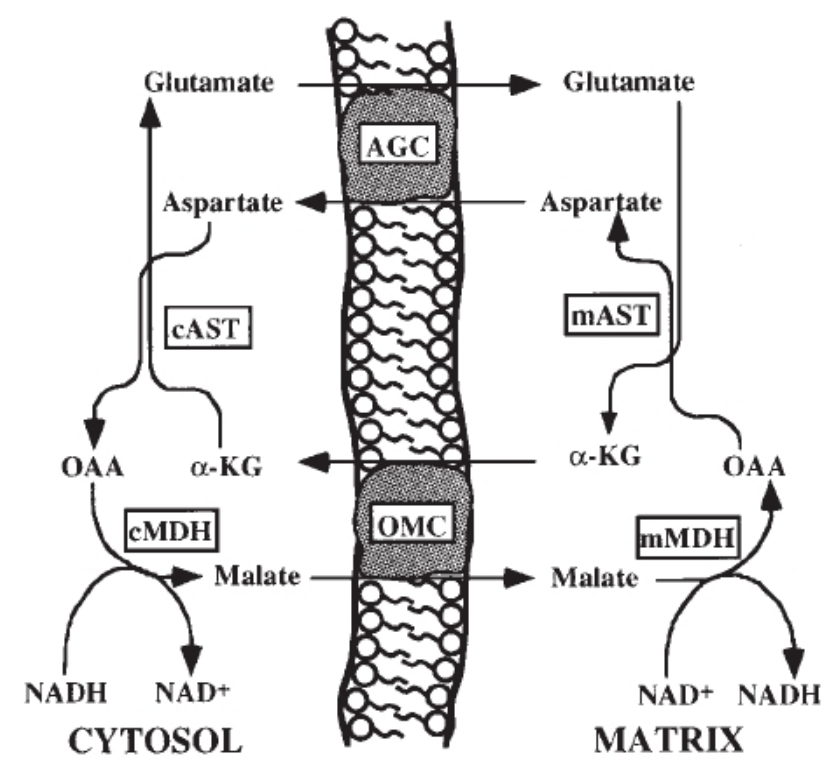

Fig. 1. Schematic of malate aspartate shuttle. A section of inner mitochondria membrane is shown. CAST and mAST, cytosolic and mitochondrial aspartate aminotransferase; $\mathrm{CMDH}$ and $\mathrm{mMDH}$, cytosolic and mitochondrial malate dehydrogenase; AGC, aspartate glutamate carrier; $\mathrm{OMC}$, oxoglutarate malate carrier; OAA, oxaloacetate.

The crucial function of L-malate in cellular metabolism is to control the influx of NADH into the mitochondria for oxidative phosphorylation and subsequent energy production. However, its function as an antioxidant remains unclear. Thus, this investigation focused on the effects of L-malate on gene expression of carried proteins and antioxidant enzymes in the liver and heart of aged rats.

\section{Materials and Methods}

\section{Preparation of chemicals}

L-malic acid was provided by Guangdong HuanKai Microbial Sci. \& Tech. Co., Ltd. (Guangzhou, China). RNAprep Pure Tissue Kit Total RNA (DP431) and animal tissue extraction kit (DP431) were purchased from TIANGEN Ltd. (Beijing, China). PrimeScript ${ }^{\mathrm{TM}}$ RT reagent Kit (Perfect Real Time) (RR037A) and SYBR ${ }^{\circledR}$ Premix Ex Taq ${ }^{\mathrm{TM}}$ (Tli RNaseH Plus) (DRR420A) were obtained from TaKaRa (Otsu, Japan). The primers were synthesized by Shanghai Sangon Biological Engineering Co., and a real-time PCR instrument (Mastercycle Eppendorf realplex) was acquired from Eppendorf (Germany).

\section{Animal preparation}

Male Sprague-Dawley rats (above 18 months old, weighing approximately $480 \mathrm{~g}$ to $560 \mathrm{~g}$, specific pathogen-free) were used in this study. The rats were healthy animals maintained and housed in large spacious cages, and given food and water ad libitum. The animal room was well ventilated with a $12 \mathrm{~h}$ light $: 12 \mathrm{~h}$ dark cycle, and maintained at $21{ }^{\circ} \mathrm{C}$ to $23{ }^{\circ} \mathrm{C}$ throughout the experimental period.

\section{Grouping of animals}

The animals were divided into four groups. Group I comprised the control rats administered with physiological saline alone. Group II comprised the rats administered with L-malate at $0.105 \mathrm{~g} / \mathrm{kg}$ body weight. Group III comprised the rats administered with L-malate at $0.210 \mathrm{~g} / \mathrm{kg}$ body weight. Group IV comprised the rats administered with L-malate at $0.630 \mathrm{~g} / \mathrm{kg}$ body weight Rats were administered via the intragastric canula for 30 days, and each group consisted of 6 animals. Upon completion of the experimental period, animals were killed by cervical decapitation. The liver and heart were excised immediately, immersed in ice-cold physiological saline, and stored at $-80^{\circ} \mathrm{C}$.

\section{Total RNA extraction}

The rats were sacrificed within $1 \mathrm{~h}$ after the last administration session. The liver and heart samples were quickly dissected, rinsed with ice-cold physiological 
saline, and stored at $-80^{\circ} \mathrm{C}$. The liver and heart were homogenized with liquid nitrogen and mixed with lysate by a micro grinding homogenizer (PRO200). Total RNA was isolated using an RNAprep Pure Tissue Kit (TIANGEN DP431, Beijing, China) according to the manufacturer's instructions. A two-step extraction method was used, with Trizol followed by an RNeasy mini kit for further purification. RNA concentration and purity were determined using a NanoDrop ND-1000 spectrophotometer (NanoDrop Technologies Inc., Wilmington, DE, USA), in which all samples had a 260/280 absorbance ratio between 1.8 and 2.1. High quality RNAs were selected and stored at $-80^{\circ} \mathrm{C}$ until ready for use in cDNA synthesis.
DNA digestion and reverse transcription

Up to $1 \mu \mathrm{g}$ of RNA was converted to cDNA using a PrimeScriptTM RT reagent Kit (Perfect Real Time, RR037A, TaKaRa, Otsu, Japan) according to the manufacturer's instructions. To verify the integrity of cDNA, PCR was performed using a glyceraldehyde-3phosphate dehydrogenase (GAPDH) specific primer. The primers for real-time $\mathrm{PCR}$ of $\mathrm{AGC}$, OMC, catalase (CAT), SOD, GSH-Px, and GAPDH gene expression in this study are summarized in Table 1. Reverse transcription was performed at $37^{\circ} \mathrm{C}$ for $15 \mathrm{~min}$ (reverse transcription reaction) and $85^{\circ} \mathrm{C}$ for $5 \mathrm{~s}$ (reverse transcriptase inactivation reaction).

Table 1. Sequences of primers in SYBR real-time PCR.

\begin{tabular}{|c|c|c|c|c|}
\hline Gene & & Primer sequence & Amplicon (bp) & Reference \\
\hline GAPDH & $\begin{array}{l}\text { Forward } \\
\text { Reverse }\end{array}$ & $\begin{array}{l}\text { 5'- CGCCAGTAGACTCCACGAC-3' } \\
\text { 5'-GCAAGTTCAACGGCACAG-3' }\end{array}$ & 141 & Li et al. 2006 \\
\hline $\mathrm{OMC}$ & $\begin{array}{l}\text { Forward } \\
\text { Reverse }\end{array}$ & $\begin{array}{l}\text { 5'- CTGGCTGGGATGGGTGCT -3' } \\
\text { 5'- CAAGGCGAGTAGTGGTGTAGGTG -3' }\end{array}$ & 211 & Wu et al. 2006 \\
\hline AGC & $\begin{array}{l}\text { Forward } \\
\text { Reverse }\end{array}$ & $\begin{array}{l}\text { 5'- CTTGTTTATGGTGGCGTTCC -3' } \\
\text { 5'- GTCTTGGCATTGTCTCGTTG -3' }\end{array}$ & 255 & Wu et al. 2006 \\
\hline CAT & $\begin{array}{l}\text { Forward } \\
\text { Reverse }\end{array}$ & $\begin{array}{l}\text { 5'- TATTGCCGTCCGATTCTC -3' } \\
\text { 5'-ATGCCCTGGTCAGTCTTG -3' }\end{array}$ & 402 & Li et al. 2006 \\
\hline SOD & $\begin{array}{l}\text { Forward } \\
\text { Reverse }\end{array}$ & $\begin{array}{l}\text { 5'-GCAGAAGGCAAGCGGTGAAC-3' } \\
\text { 5'-TAGCAGGACAGCAGATGAGT-3' }\end{array}$ & 387 & Limaye et al. 2003 \\
\hline GSH-Px & $\begin{array}{l}\text { Forward } \\
\text { Reverse }\end{array}$ & $\begin{array}{l}\text { 5'-CTCACCCGCTCTTTACCTT -3' } \\
\text { 5'-AACACCGTCTGGACCTACC -3' }\end{array}$ & 158 & Li et al. 2006 \\
\hline
\end{tabular}

\section{Real-time PCR with SYBR green I}

Real-time PCR was carried out in optical grade 96-well plates using an $\mathrm{SYBR}^{\circledR}$ Premix Ex $\mathrm{Taq}^{\mathrm{TM}} \mathrm{II}$ (Perfect Real Time) kit at a reaction volume of $25 \mu \mathrm{l}$, including $12.5 \mu \mathrm{l}$ of SYBR $\AA$ Premix Ex TaqTM II $(2 \times)$, $1.5 \mu \mathrm{l}$ of primer $(10 \mu \mathrm{mol} / \mathrm{l}), 1.5 \mu \mathrm{l}$ of genomic template DNA, and $9.5 \mu \mathrm{l}$ of $\mathrm{dH}_{2} \mathrm{O}$. All samples were run in duplicate. Thermal cycling was performed on an Applied Biosystems 7300 real-time PCR system using the following cycling conditions: denaturation at $95^{\circ} \mathrm{C}$ for $5 \mathrm{~s}$, annealing/extension at $55^{\circ} \mathrm{C}$ for $20 \mathrm{~s}$, and 40 cycles. The fluorescence intensity data were continuously collected over the ramping stage for $20 \mathrm{~min}$. Melting curve analysis was performed according to the dissociation stage data, and reactions with a single peak at the expected melting temperature $\left(T_{\mathrm{m}}\right)$ were considered for further analysis.

\section{Data analysis}

Quantitative analysis was performed by measuring the threshold cycle (CT) values during the exponential phase of amplification. CT was defined as the cycle number at which the amplification plot passed a fixed threshold. In each assay, $\mathrm{mCT}$ was the mean CT of duplicate amplifications. The relative quantities of AGC, OMC, CAT, SOD, GSH-Px, and GAPDH genes were determined using comparative $\mathrm{Ct}$ method, and $\Delta \mathrm{Ct}$ was calculated as the difference between the $\mathrm{Ct}$ values of AGC, OMC, CAT, SOD, and GSH-Px and the Ct value of GAPDH gene. Data were analyzed using the following formula: gene dosage ratio $=2^{-\Delta \Delta} \mathrm{Ct}$, where ${ }^{-\Delta \Delta} \mathrm{Ct}=[\mathrm{mCt}$ AGC, OMC, CAT, SOD, GSH-Px (normal sample) - 

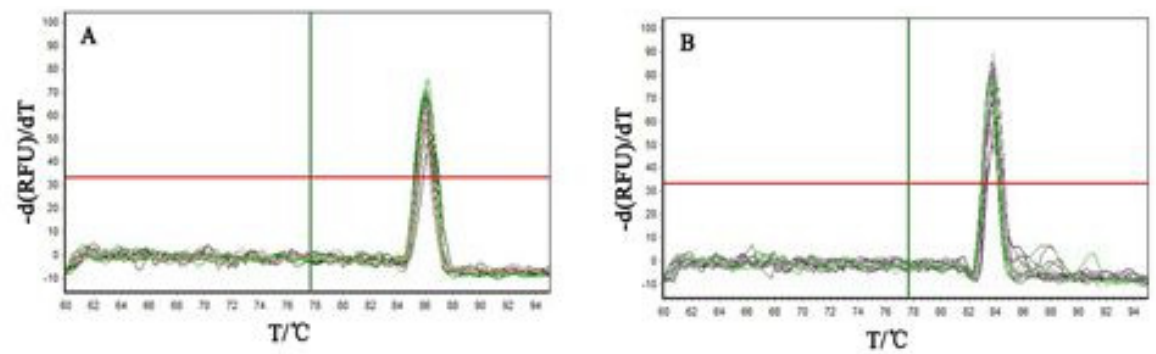

Fig. 2. The melting curve of different target genes in heart of aged rats. A: GADPH, B: AGC, C: OMC, D: CAT, E: GSH-PX, F: SOD.
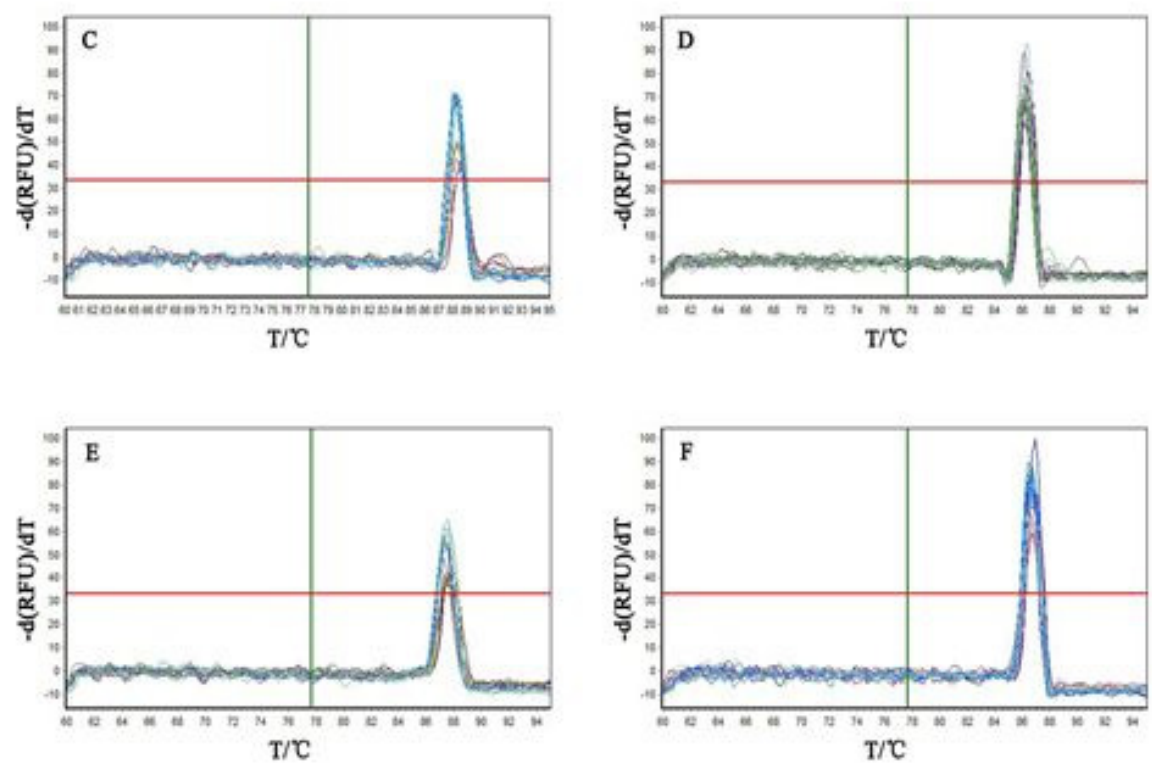

mCt GAPDH gene (normal sample)] - [mCt AGC, OMC, CAT, SOD, GSH-Px (test sample) - mCt GAPDH gene (test sample)] (Yakubov et al. 2004). Gene dosage ratios were relative to the mean $\Delta \mathrm{Ct}$ value of these samples. Data processing was analyzed using an ABI Prism 7300 Sequence Detection System (version 1.2.3, Applied Biosystems, UK). The original data were evaluated using SPSS 10.0 software. All results are presented as mean \pm SD. One-way ANOVA was used for statistical analysis, and all tests were considered to be statistically significant at $* \mathrm{P}<0.05$ or very significant at $* * \mathrm{P}<0.01$.

\section{Results}

Melting curve and amplification curve analysis

Figures 2 and 3 show the melting curves of GADPH, AGC, OMC, CAT, SOD, and GSH-Px genes in cardiomyocytes and liver cells, respectively. Melting curve analysis was performed for every single reaction to exclude the amplification of non-specific products. The figures represent the valid amplification reactions of GADPH, AGC, OMC, CAT, SOD, and GSH-Px genes from myocardial cells, and liver cells displayed a single peak.

To optimize and validate the results of real-time PCR assay before using the $2^{-\Delta \Delta} \mathrm{Ct}$ method for gene expression, validation experiments were performed to determine the PCR efficiencies of the target and reference genes. Figures 4 and 5 show the amplification curves of GADPH, AGC, OMC, CAT, SOD, and GSH-Px genes in cardiomyocytes and liver cells, respectively. These figures show similar shapes in the amplification curve of the target and reference genes. Figures 4 and 5 show that the amplification of the target and reference genes demonstrated relatively consistent efficiency, which indicates the validity of the $2^{-\Delta \Delta} \mathrm{Ct}$ relative quantitation.

Effect of L-malic acid on gene expression of $A G C, O M C$, $C A T, S O D$, and GSH-Px in the heart and liver

The effects of L-malate supplementation on gene expression for AGC, OMC, CAT, SOD, and GSH-Px genes in the liver and heart of aged rats were examined. Results show that GADPH gene expression was unaffected by L-malate treatment. Figure 6 shows that gene expression of OMC and GSH-Px increased $(\mathrm{P}<0.05)$ by $39 \%$ and $38 \%$, respectively, in the liver of the $0.630 \mathrm{~g} / \mathrm{kg}$ body weight group (Group IV) than that in the control (Group I). Dietary L-malate enhanced $(\mathrm{P}<0.05)$ 
gene expression of SOD in the liver of the $0.105 \mathrm{~g} / \mathrm{kg}$ (Group II) and $0.210 \mathrm{~g} / \mathrm{kg}$ body weight groups (Group III) than those in the control (Group I). L-malate administration significantly increased $(\mathrm{P}<0.01)$ the gene expression level of SOD in the liver of the $0.630 \mathrm{~g} / \mathrm{kg}$ body weight group (Group IV) by $78 \%$ than that in the control (Group I). The expression levels of SOD mRNA in the liver increased $(\mathrm{P}<0.05)$ by $39 \%$, and $56 \%$ in the 0.105 and $0.210 \mathrm{~g} / \mathrm{kg}$ L-malate treatment groups, respectively. However, L-malate had no effect on the gene expression levels of AGC, OMC, CAT, SOD, and GSH-Px in the heart of aged rats (Fig. 7).
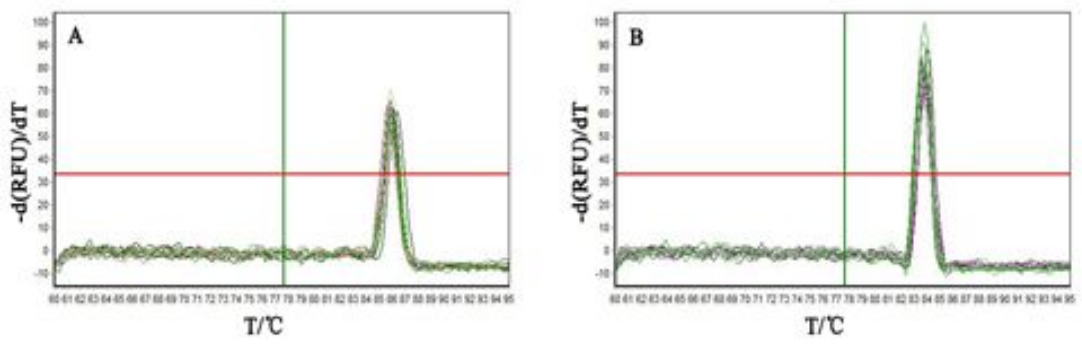

Fig. 3. The melting curve of different target genes in liver of aged rats. A: GADPH, B: AGC, C: OMC, D: CAT, E: GSH-Px, F: SOD.
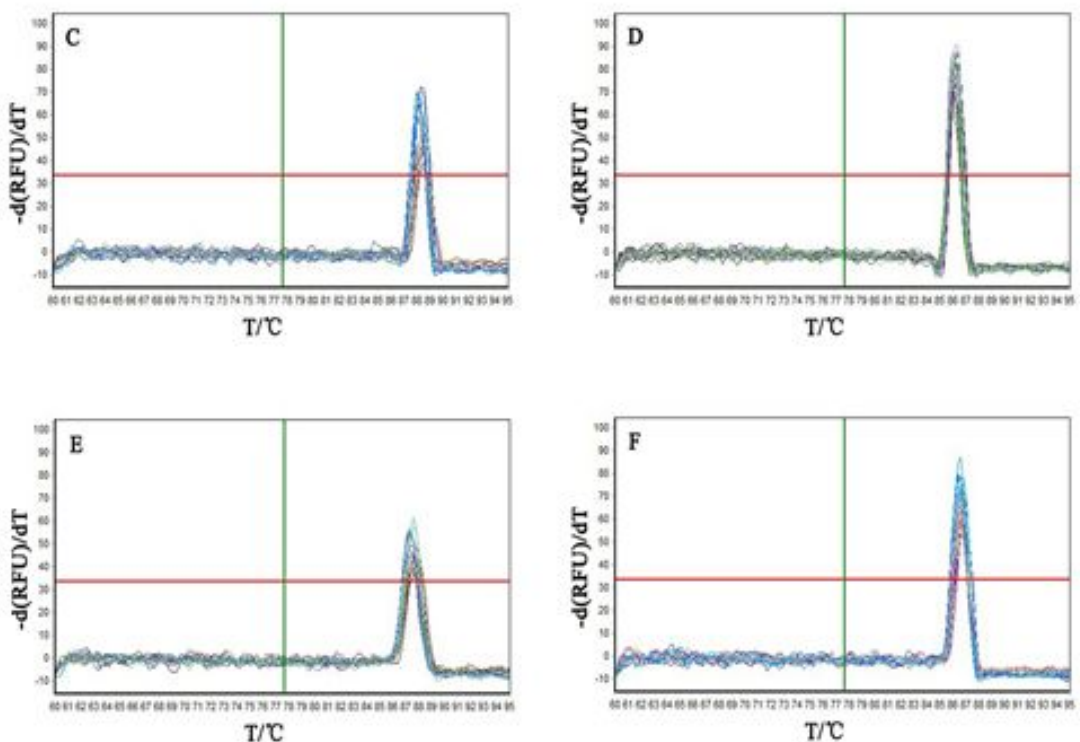

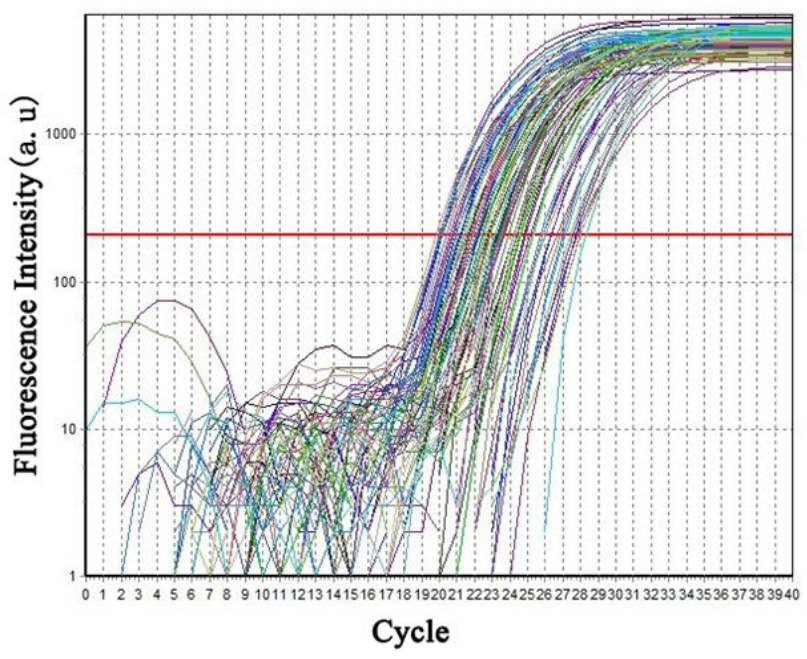

Fig. 4. The amplification curves of $G A D P H, A G C, O M C, C A T$, GSH-Px and SOD gene in heart of aged rats.

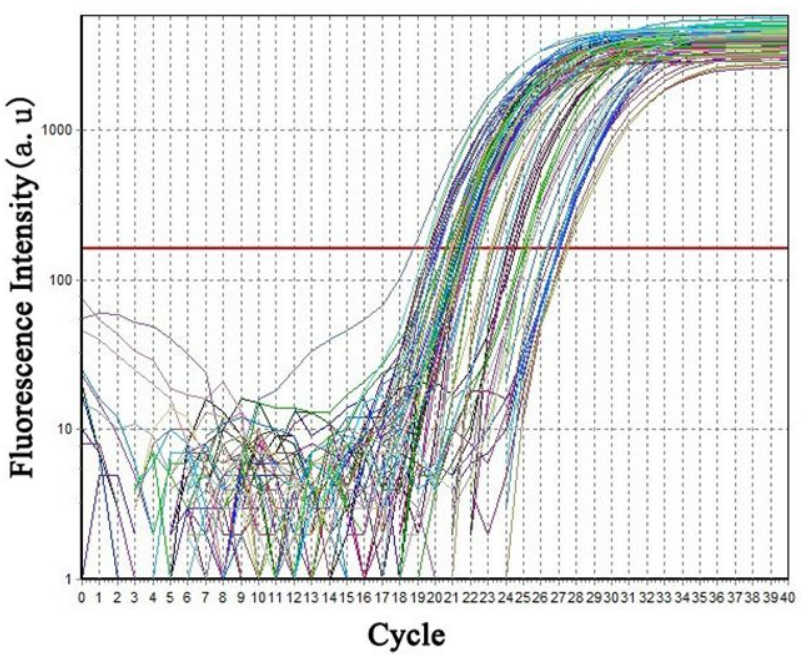

Fig. 5. The amplification curves of GADPH, AGC, OMC, CAT, GSH-Px and SOD gene in liver of aged rats. 

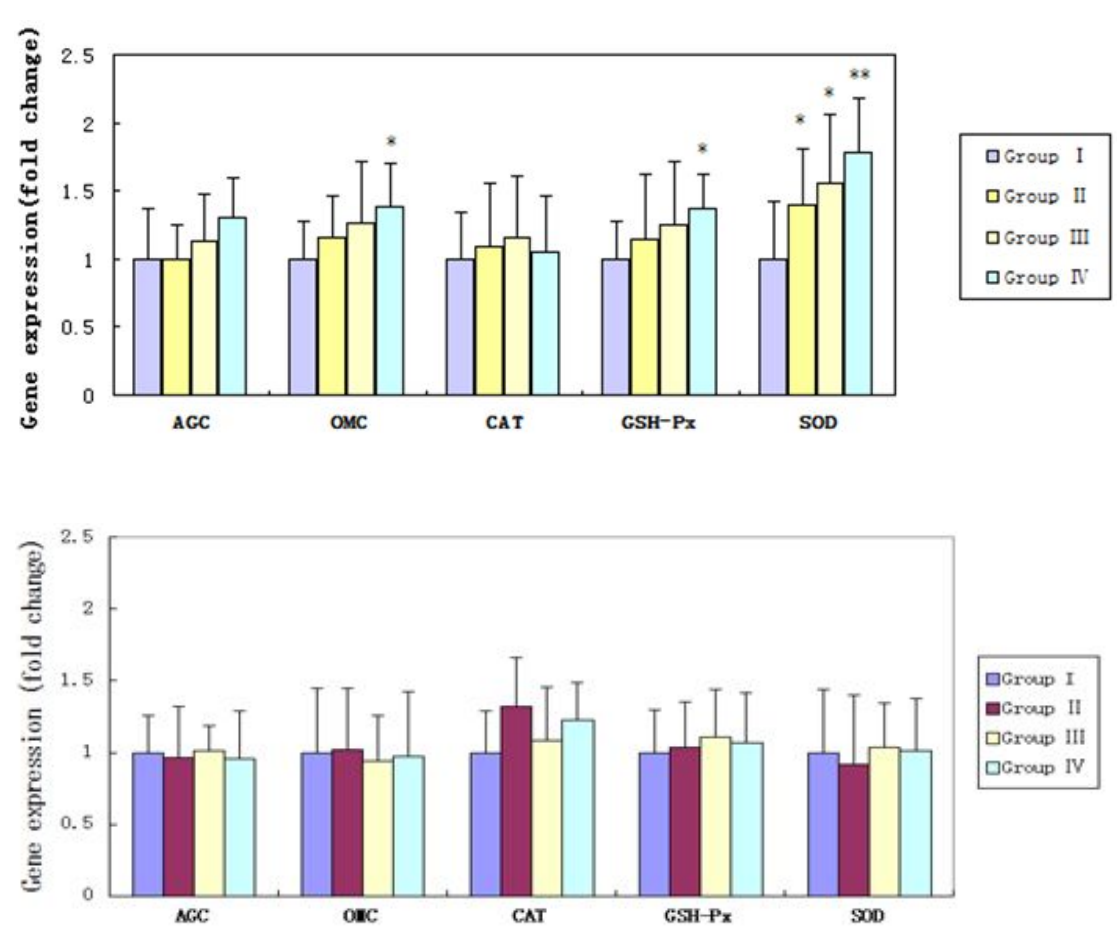

Fig. 6. Gene expression for $A G C, O M C$, CAT, GSH-Px and SOD genes in liver of control and L-malate treated rats. Values are the means $\pm S D(n=6$, respectively). $* \mathrm{P}<0.05$ and $* * \mathrm{P}<0.01$ indicates significant compared with control rats (Group I).

\section{Discussion}

An investigation of the relationship between expression changes in carried proteins and antioxidant enzymes and antioxidative status has provided important information to improve the understanding of the physiological functions of L-malate in reducing oxidative stress in the liver and heart of aged rats. Thus, this study focused on examining the effects of L-malate on the gene expression levels of carried proteins and antioxidant enzymes in the liver and heart of aged rats by SYBR Green I using real-time RT-PCR.

Studies have shown that mitochondrial function declines with increasing age (Trounce 1989, Ozawa 1997). Some in vitro experiments have demonstrated that antioxidant supplements may enable the mitochondria to adapt to changes, including increased volume, number of mitochondria, and increased synthesis and activity of the enzyme, thereby improving oxidative phosphorylation (Arivazhagan 2001). Malic acid supplements can increase the level of aerobic metabolism and aerobic capacity in the body (Bendahan 2002). Strengthened mitochondrial respiration may be caused by catecholamines, glucagon, and exercise, in which case the concentration of mitochondrial malate increases. The increase in mitochondrial malate is responsible for the increase in oxidation rate (Bobyleva-Guarriero et al. 1986a,b). Agbanyo et al. (1986) observed that the driving force of mitochondrial ATP production is L-malate, and postulated that respiration is reinforced by malic acid.
Fig. 7. Gene expression for AGC, OMC, CAT, GSH-PX and SOD genes in heart of control and L-malate treated rats. Values are the means $\pm S D(n=6$, respectively). $* P<0.05$ and ${ }^{*} * \mathrm{P}<0.01$ indicates significant compared with control rats (Group I).
Bobyleva-Guarriero et al. (1986a) found that rats injected with a small amount of malate yield liver mitochondria with increasing malate concentration and oxidation rate of citrate, $\alpha$-ketoglutarate, and succinate. An increased demand for ATP (energy) denotes an increased demand for malic acid (Guy and Jorge 1992). The high-energy substance ATP was generated by enzymatic reactions of the respiratory chain located in the inner mitochondrial membrane. In our previous study, we found that L-malate can reduce ROS generation by increasing the efficiency of electron transport and enhancing the activity of energy metabolism ( $\mathrm{Wu}$ et al. 2011). All these experiments showed that L-malic acid improves mitochondrial function and enhances mitochondrial antioxidant status.

AGC and OMC are two important transport proteins of MAS. AGC, as a potential driver (electrogenically driven) protein, is the rate-limiting step of MAS metabolism (LaNoue and Tischler 1974, Kunz and Davis 1991), and its activity is determined by the mitochondrial membrane potential. MAS is regulated by the protein levels of $\mathrm{OMC}$ and $\mathrm{AGC}$ in the inner mitochondrial membrane (LaNoue and Tischler 1974). The efficiency of MAS in the liver of the plateau zokor improves by upregulating the gene expression of AGC, as measured by real-time PCR (Zhu et al. 2012). Scholz (1998) demonstrated that the MAS capacity increases in neonatal heart and may be regulated at the level of OMC gene expression. A previous study demonstrated that the efficiency of MAS increases by L-malate 
supplementation (Wu et al. 2007). In the present study, we found a significant increase in OMC gene expression and an increasing trend of AGC gene expression in the liver of aged rats. Thus, the efficiency of MAS may be regulated by gene expression of OMC. DNA damage ensuing from aging is related to the destruction of DNA spirals by active oxygen, thereby resulting in protein deformation and metabolic functional problems. The gene expression of $\mathrm{Cu} / \mathrm{Zn}-\mathrm{SOD}$ and GSH-Px is reduced in the liver of aged rats (Kim et al. 2002). However, a significant increase in the gene levels of these enzymes in the liver of aged rats treated with L-malate was observed in our study. The increase in expression of these enzymes was not found in the heart, which suggests a correlation between different levels of oxidative stress and aging in these two organs. The increase in the expression of SOD and GSH-Px mRNA activated sufficient SOD and GSH-Px to scavenge the radicals, thereby protecting cells.

In this study, the expression of mRNAs for AGC, OMC, CAT, SOD, and GSH-Px was confirmed in the liver and heart of aged rats. L-malate significantly increased the expression levels of mRNAs for OMC, SOD, and GSH-Px in the liver of aged rats. The expression level of mRNA for AGC also increased by L-malate administration. L-malate had no significant effect on the expression levels of mRNAs for CAT and AGC in the liver of aged rats. Moreover, L-malate had no significant effect on the expression levels of mRNAs for AGC, OMC, CAT, SOD, and GSH-Px in the heart of aged rats. These differences may be related to the status of liver as the organ of energy metabolism. These findings suggest that L-malate was capable of enhancing the ability of mitochondrial antioxidant status by upregulating the expression levels of mRNAs for OMC, SOD, and GSH-Px in the liver of aged rats. Our findings will contribute to the molecular elucidation of the antioxidative mechanisms of L-malate.

\section{Conflict of Interest}

There is no conflict of interest.

\section{Acknowledgements}

This study was supported by grants from the Foundation for National Natural Science Foundation of China (31000762 and 31271940) and Pearl River Nova Program of Guangzhou (2013J2200079).

\section{References}

AGBANYO FR, MOSES G, TAYLOR NF: L-malate transport and proton symport in vesicles prepared from Pseudomonas putida. Biochem Cell Biol 64: 1190-1199, 1986.

ARIVAZHAGAN P, RAMANATHAN K, PANNEERSELVAM C: Effect of DL-a-lipoic acid on mitochondrial enzymes in aged rats. Chem Biol Interact 138: 189-198, 2001.

BENDAHAN D, MATTEI JP, GHATTAS B, CONFORT-GOUNY S, LE GUERN ME, COZZONE PJ: Citrulline/ malate promotes aerobic energy production in human exercising muscle. Br J Sports Med 36: 282-289, 2002.

BOBYLEVA-GUARRIERO B, LARDY HA: The role of malate in exercise-induced enhancement of mitochondrial respiration. Arch Biochem Biophys 245: 270-276, 1986a.

BOBYLEVA-GUARRIERO V, WEHBIE RS, LARDY HA: The role of malate in hormone-induced enhancement of mitochondrial respiration. Arch Biochem Biophys 245: 477-482, $1986 \mathrm{~b}$.

ETO K, TSUBAMOTO Y, TERAUCHI Y, SUGIYAMA T, KISHIMOTO T, TAKAHASHI N, YAMAUCHI N, KUBOTA N, MURAYAMA S, AIZAWA T, AKANUMA Y, AIZAWA S, KASAI H, YAZAKI Y, KADOWAKI T: Role of NADH shuttle system in glucose-induced activation of mitochondrial metabolism and insulin secretion. Science 283: 981-985, 1999.

GUY EA, JORGE DF: Management of fibromyalgia: rationale for the use of magnesium and malic acid. J Nutr Environ Med 3: 49-59, 1992.

KIM MJ CHOI JH, YANG JA, KIM SY, KIM JH, LEE JH, KIM JK, RHEE SJ: Effects of green tea catechin on enzyme activities and gene expression of antioxidative system in rat liver exposed to microwaves. Nutr Res $\mathbf{2 2}$ : 733-744, 2002.

KUNZ WS, DAVIS EJ: Control of reversible intracellular transfer of reducing potential. Arch Biochem Biophys 284: 40-46, 1991. 
LANOUE KF, TISCHLER ME: Electrogenic characteristics of the mitochondrial glutamate-aspartate antiporter. $J$ Biol Chem 249: 7522-7528, 1974.

LI H, JIANG T, LIN Y, ZHAO Z, ZHANG N: HGF protects rat mesangial cells from high-glueose-mediated oxidative stress. Am J Nephrol 26: 519-530, 2006.

LIMAYE PV, RAGHURAM N, SIVAKAMI S: Oxidative stress and gene expression of antioxidant enzymes in the renal cortex of streptozotocininduced diabetic rats. Mol Cell Biochem 243: 147-152, 2003.

OZAWA T: Genetic and functional changes in mitochondria associated with aging. Physiol Rev 77: 425-464, 1997.

SCHOLZ TD, TENEYCK YJ, CCHUTTE BC: Thyroid hormone regulation of the NADH shuttles in liver and cardiac mitochondria. Mol Cell Cardiol 32: 1-10, 2000.

SCHOLZ TD, KOPPENHAFER SL, TENEYCK CJ, SCHUTTE BC: Ontogeny of malate-aspartate shuttle capacity and gene expression in cardiac mitochondria. Am J Physiol Cell Physiol 274: C780-C788, 1998.

TROUNCE I, BYRNE E, MARZUKI S: Decline in skeletal muscle mitochondrial respiratory chain function: Possible factor in ageing. Lancet 8639: 637-639, 1989.

WU JL, WU QP, WEI MK, WU HQ, ZHOU XY: Effect of L-malate on gene expression of proteins and enzymes related to the malate-aspartate shuttle (in Chinese). Food Sci 11: 229-232, 2006.

WU JL, WU QP, HUANG JM, CHEN RY, CAI M, TAN JB: Effects of L-malate on physical stamina and activities of enzymes related to the malate-aspartate shuttle in liver of mice. Physiol Res 56: 213-220, 2007.

WU JL, WU QP, YANG XF, WEI MK, ZHANG JM, HUANG Q, ZHOU XY: L-malate reverses oxidative stress and antioxidative defenses in liver and heart of aged rats. Physiol Res 57: 261-268, 2008.

WU JL, WU QP, PENG YP, ZHANG JM: Effects of L-malate on mitochondrial oxidoreductases in liver of aged rats. Physiol Res 60: 329-336, 2011.

YAKUBOV E, GOTTLIEB M, GIL S, DINERMAN P, FUCHS P, YAVIN E: Overexpression of genes in the CA1 hippocampus region of adult rat following episodes of global ischemia. Brain Res Mol Brain Res 127: 10-26, 2004.

ZHU RJ, RAO XF, WEI DB, WANG DW, WEI L, SUN SZ: Functional difference of malate-aspartate shuttle system in liver between plateau zokor (Myospalax baileyi) and plateau pika (Ochotona curzoniae) (in Chinese). Acta Physiol Sinica 64: 177-186, 2012. 